\title{
RURAL-URBAN MULTIPLIER AND POLICY EFFECTS IN FINISH RURAL REGIONS: AN INTER-REGIONAL SAM ANALYSIS
}

\author{
Nina Hyytiä ${ }^{1}$
}

Received 3 May 2013; Accepted 13 December 2013

\begin{abstract}
The paper studies rural policies in two Finnish regions, and whether the policy benefits would accumulate to the rural or urban areas. Rural-urban social accounting matrices were built and used as a base data for the SAM multiplier analysis. The output multiplier values demonstrate the important role of agriculture and food industry in both of the study regions. In the urban areas, however, services and construction were among the industries with the highest income generating potential. Whilst urban and rural industries had almost an equal potential for stimulating the whole economies, the results indicate that urban activities spill over welfare to the surrounding rural areas and thus can back up the development of the whole regions. Due to their different economic structures, South Ostrobothnia responded stronger to the agricultural policies while North Karelia was more responsive to the infrastructure and tourism policies.
\end{abstract}

Keywords: rural, social accounting matrix, SAM model

Tiivistelmä: Artikkelissa tutkitaan maaseutupolitiikkojen vaikutuksia ja niiden hyötyjen jakautumista maaseutu- ja kaupunkialueiden kesken kahdessa Suomen maakunnassa. Tutkimusmenetelminä ovat sosiaalisen tilinpidon matriisit ja SAMkerroinanalyysit. Maatalous ja elintarviketeollisuus olivat edelleen tärkeitä näille maakunnille. Kaupunkialueilla palvelut ja rakentaminen kuitenkin loivat eniten taloudellista toimeliaisuutta kytkentöjensä kautta. Vaikka maaseudun ja kaupunkien toimialat olivat alueellisen aktiivisuuden luojina lähes tasaväkisiä, kaupunkien toimialat levittivät enemmän hyötyjä myös maaseutualueille ja tukivat siten koko maakuntien kehitystä. Erilaisista talouden rakenteista johtuen Etelä-Pohjanmaa reagoi voimakkaammin maatalouspolitiikkoihin, kun taas infrastruktuuri- ja turismipolitiikat olivat suhteellisesti tärkeämpiä Pohjois-Karjalalle.

\section{Introduction}

In Finland, rural development has traditionally been supported by a mix of separate regional, agricultural and rural policies. Recently, however, previously typical sector-specific income support has been transformed towards measures that could underpin competitiveness and in

\footnotetext{
${ }^{1}$ Nina Hyytiä, University of Helsinki, Department of Economics and Management, P.O.Box 27, FI-00014 Helsinki, Finland, e-mail: nina.hyytia@helsinki.fi
} 
addition, take account of area specific economic and social needs. These measures aim at reinforcing long-term structural changes, enhancing the competitiveness of rural enterprises, improving rural employment and promoting spatial and regional equality and cohesion (e.g. Ministry of Agriculture and Forestry, 2007). Such development follows the path chosen by the European Union, which calls for more coherent rural and cohesion policies and coordination among EU funds (e.g. Assembly for European Regions, 2010).

European rural policy is settled at the boundary of the two major interests and concerns of the European Union. The first is structural policy, which concerns the promotion of productivity, competitiveness of economic activities, and simultaneously, equity among countries, regions and sectors. The second is agricultural policy, which aims at securing farm incomes and rural livelihood, and sustainable development of agriculture. Within the EU, the term rural development is most often used in the context of the CAP Second Pillar, while in the regional policy context it is used more generally over a variety of measures that aim at enhancing welfare in rural areas (Thomson et al., 2010).

Regional economics addresses where and why economic activity takes place. In addition to traditional economics, regional economics draws on location theory, urban economics and international trade theories (Fujita and Krugman, 2004). Hence, the key concepts of regional economics and economic agglomeration are grounded on these theories. The term agglomeration signifies the concentrations or clusters that appear in terms of geographic levels (Mulligan, 1984). In the 1920s, Alfred Marshall defined knowledge spillovers, the advantages of thick markets for specialised skills, and the backward and forward linkages associated with large local markets as the sources of agglomeration economies. Later, Fujita and Krugman (2004) distinguished linkages, thick markets and knowledge spillovers as the main centripetal forces that accelerate accumulation. Correspondingly, immobile factors, land rents, commuting and congestion are centrifugal forces that encourage dispersion.

In spite of a number of studies on how (EU) policies affect regional development (for example Baldwin et al., 2003; Balkhausen et al., 2008; Boldrin and Canova, 2001; Puga, 2002; Shankar and Shah, 2009), studies on whether the policies induce agglomeration or dispersion within a rural region are still relatively few. An early study was Round (1985), who constructed a biregional Social Accounting Matrix (SAM) for analysing the relationship between East and West Malaysia. The SAM multiplier analysis reported relatively low regional interdependencies. Later, Roberts (1998) analysed the spatial diffusion of rural-urban spillover effects in Grampian, Scotland. One of her main findings was that the rural multipliers were greater than the urban multipliers, indicating the greater income-generating potential of rural industries. In addition, inter-regional linkages were more important for urban industries, indicating that urban industries are dependent on rural household demand and rural factor services. This finding opposed the general perception that rural areas are open, without diversified economic structure and thus lack an ability to fully exploit the benefits of increased investment. By applying a corresponding multiplier model, Psaltopoulos et al. (2006) evaluated the inter-regional impacts of the CAP in two rural and one urban area in Greece. They concluded that the rural areas leak benefits to the urban area.

Kilkenny $(1993,1998)$ examined the effects of farm subsidy termination and transport costs by using a rural-urban computable general equilibrium (CGE) model. She deduced (1993) that termination of farm subsidies would result in local losses in the short-run. However, the results also suggested that farm subsidies in fact undermine other rural activity. The latter study (1998) showed that reductions in transport costs facilitated concentration. Yet, the relationship between transport costs and rural development was nonlinear, such that if transport costs were high, the reductions favoured concentration, whereas if the industrial transport cost rates were relatively low, further reductions favoured the industrial development of a natural-resourcebased economy. Recently, Daniel and Kilkenny (2009) studied whether coupled subsidies and single farm payments can decrease spatial agglomeration and whether the benefits of subsidising agriculture in an attempt to promote rural development can outweigh the costs. They found that only the single farm payment raised welfare in both the rural and the urban region. However, both the coupled and the single farm payments countervailed against urban agglomeration such that they encouraged firms to locate in lower-density regions. 
The studies above base their analysis on the economic linkages through which the different policy shocks enter the local economy, which finally attains a new economic equilibrium. The concept of linkages among local industrial sectors is essential to virtually every theory of regional economic growth (Kraybill and Dorfman, 1992). Consideration of agglomeration and dispersion through rural-urban linkages is important since rural-urban connections are often vital for the development of remote rural areas. For example, Durandon and Puga (2002) argue that, within the mature urban system, technological shocks and innovations can spill over into hinterlands. Further, rural surroundings can attain positive spread effects such as special services and urban jobs through commuting (Henry et al., 1997; Partridge et al., 2008).

This paper examines two Finnish rural provinces (NUTS3) South-Ostrobothnia and North Karelia, and their urban centres Seinäjoki and Joensuu. It studies whether the corresponding policy shocks have different effects on the regions due to, for example, their different economic structures. The second aim is to consider how important a role different industries, particularly agriculture, transportation and tourism, have on the regions. These are among the industries that are often singled out as sectors which have the ability to enhance rural development. Thirdly, the paper examines whether the impacts are different in rural and urban areas: do the urban centres collect the benefits of the policies implemented in the rural provinces?

\section{Study areas}

South Ostrobothnia and North Karelia (NUTS3) face typical problems of rural provinces in need of assistance. Their per capita GDP is below the Finnish national average, considerable outmigration of the working-age population occurs, and both provinces are relatively dependent on primary industries and transfers from other parts of Finland and the EU. In addition, North Karelia has consistently suffered from high unemployment. South Ostrobothnia has 193,000 inhabitants (of which the urban area Seinäjoki accounts for 37,000 ), corresponding to $3.4 \%$ of the Finnish population. Agriculture and forestry account for relatively larger shares of value added (9\%), employment (11\%) and trade compared with the national average. In 2008, there were 7,390 farms in South Ostrobothnia, making up $11 \%$ of the Finnish farms. The average farm size is 33 ha (in Finland 35 ha). The local farms own 12\% of the Finnish cattle, $17 \%$ of the pigs, $22 \%$ of the poultry, and they produce $11 \%$ of the Finnish milk

North Karelia is characterised by a low population density. The province is inhabited by 166,000 people including the urban area of Joensuu, which has 57,000 inhabitants. As opposed to South Ostrobothnia, the forestry cluster is more important compared to the food cluster in North Karelia. However, agriculture is important for this region too. In 2008, there were 2,704 farms in North Karelia, contributing $4 \%$ of the Finnish farms. The average farm size is 32 ha. The local farms have $6 \%$ of the Finnish cattle, $0.8 \%$ of the pigs, $0.2 \%$ of the poultry and they produce $6 \%$ of the Finnish milk. Dairy production is the most important agricultural production line in North Karelia. Apart from forestry and food, the most important economic sectors are plastic, metal and stone industries.

\section{Data and Methodology}

\section{Social Accounting Matrices}

A Social Accounting Matrix aims at recording all the economic activities, such as consumption, production, accumulation, and distribution taking place during an accounting period. The particular strength of a SAM is its capability to capture the complex linkages among institutions, production and the rest of the world (Pyatt and Round, 1985). In this accounting framework, the included accounts are represented as a square matrix in which incomes and expenditures are shown as corresponding rows and columns of the matrix thus displaying the circular flows of income in the regions. In particular, it records the interactions between institutions and production activities through both factor and product markets (Round 2003).

The SAMs were built in order to capture the rural-urban linkages of the study areas. The data was collected from various secondary and primary sources. The regional input-output tables of Statistics Finland (2006), relating to the year 2002 were used as core information. The tables comply with the concepts of the European System of Accounts (ESA95) and the UN System of 
National Accounts 1993. The industrial classification used is based on the national standard industrial classification TOL2002, and the product classification follows the activity-based product classification CPA of the European Union. The most important sources in compiling regional $\mathrm{I}-\mathrm{O}$ tables have been regional accounts, national accounts, statistics on industrial structure and products, structural statistics on service industries, statistics on foreign trade, the register of enterprises and establishments, corporate taxation reports, statistical databases of central and local governments, statistics on agriculture and forestry, and the Household Budget Survey (Statistics Finland, 2006).

In order to complete the division between urban and rural areas, more precise information at the municipal level was needed. This information originated from the regional statistics source of Statistics Finland (ALTIKA), databases of local public and private actors, and tax authorities. Compared to the regional I-O- tables, the SAMs are far more detailed as factors of production, households, government accounts, and Rest of the World and Savings-Investments accounts are concerned. All the core information relates to the calendar year 2002. Regardless of the availability of high quality and relatively extensive secondary data in Finland, primary data was also collected for the SAM construction in order to fill the remaining information gaps. Accordingly, both business and household surveys were carried out during autumn 2006. Since the major part of the material was collected for other research purposes, the surveys are not covered here in detail. In the end, the SAM was balanced by using a cross entropy method, which corrects imbalances in the data by minimising the entropy distance of the cells of the estimated SAM subject to the constraint that row and column totals should be equal (Robinson et al., 2000).

The general structure of the rural-urban SAMs is shown in Appendix 1. The SAMs have 27 and 25 accounts for rural and urban activities, respectively. For the multiplier analysis, however, the accounts were aggregated to 15/13. The division between rural and urban industries is based on the statistics of the enterprise location by industries and regions as well as information on workplaces by industries and municipalities. Table 1 shows the most important sectors in terms of value added. The commodities accounts are identical across the whole study region since commodity markets are highly integrated inside the study regions. Altogether, there are 27 accounts for commodities and services.

\begin{tabular}{|l|r|r|l|l|r|r|}
\hline North Karelia & Mill $€$ & $\%$ & & South Ostrobothnia & Mill $€$ & $\%$ \\
\hline TOTAL GVA & 2932 & 100 & & TOTAL GVA & 3424 & 100 \\
Rural GVA & 1724 & 59 & & Rural GVA & 2587 & 76 \\
A-Rforestry & 200 & 7 & & A-Ragriculture & 320 & 9 \\
A-Rhealth & 165 & 6 & & A-Rhealth & 237 & 7 \\
A-Rtransport & 151 & 5 & & A-Rtrade & 217 & 6 \\
A-Rtrade & 120 & 4 & & A-Rtransport & 162 & 5 \\
A-Ragriculture & 118 & 4 & & A-Rfood & 158 & 5 \\
Urban GVA & 1208 & 41 & & Urban GVA & 837 & 24 \\
A-Ueducation & 139 & 5 & & A-Utrade & 107 & 3 \\
A-Uhealth & 135 & 5 & & A-Uhealth & 106 & 3 \\
A-Utransport & 92 & 3 & & A-Utransport & 95 & 3 \\
A-Utrade & 87 & 3 & A-Ueducation & 65 & 2 \\
A-Ubusiness services & 76 & 3 & A-Uconstruction & 58 & 2 \\
\hline
\end{tabular}

Tab 1. Most important sectors in terms of value added.

Labour was distinguished to blue-collar and white-collar workers. The classification was based on the information attained from regional and industrial statistics and educational sources. The capital accounts are rural capital, urban capital, and agricultural capital. The agricultural land factor was separated and accounts for rural housing rent and urban housing rent were distinguished. There are six different household groups: agricultural households, rural and urban working households, commuter households, rural and urban other households that 
include pensioner, students and unemployed households that earn their income from income transfers and from capital income, and finally, tourist households. In addition, there are accounts for government, a rest of the world account that includes both the rest of Finland and other countries, and an account for savings and investments.

\section{Multiplier analysis}

In multiplier analysis, SAM accounts are partitioned into endogenous and exogenous accounts. Endogenous accounts are those that react to the changes in incomes in the model, while exogenous accounts are those, expenditures of which are set independently of income. Typically, transactions in the government account, the capital account, and the rest-of-the-world account are regarded as exogenous, since government outlays are essentially policydetermined, the external sector is not under domestic control, and investments are exogenously determined because the model is static. A shock is introduced into the model by changing one of the exogenous accounts. As a consequence of the injection, the model provides solution for the equilibrium level of all the endogenous accounts. (Sadoulet and de Janvry, 1995; Round, 2003.)

A bi-regional SAM multiplier model is expressed here by following Round (1985) and Roberts (1998). As production, factor and household accounts are endogenous, the basic row accounting balances can be written as $y=B y+x$ where $y$ is a column vector of endogenous account totals in both areas, $B$ a normalised transaction coefficients matrix that includes both intra- and interregional sub-matrices of the SAM, and $x$ is a column vector that shows flows from the endogenous accounts to the combined exogenous account. Assuming that the matrix $B$ has constant elements, the aggregate multipliers can be solved by using matrix inversion: as $y=(I-B)^{-1} x=M x$.

The partitioned form of the inter-regional SAM can be expressed as follows:

$$
\left[\begin{array}{l}
y_{1} \\
y_{2}
\end{array}\right]=\left[\begin{array}{ll}
B_{11} & \tilde{b}_{12} \\
\tilde{b}_{21} & B_{22}
\end{array}\right]\left[\begin{array}{l}
y_{1} \\
y_{2}
\end{array}\right]+\left[\begin{array}{l}
x_{1} \\
x_{2}
\end{array}\right]
$$

Here subscripts 1 and 2 refer to sub regions, and a superscript to a diagonal sub-matrix.

From equation ( 1 ),

$$
\begin{gathered}
{\left[\begin{array}{l}
y_{1} \\
y_{2}
\end{array}\right]=\left[\begin{array}{cc}
B_{11} & 0 \\
0 & B_{22}
\end{array}\right]\left[\begin{array}{l}
y_{1} \\
y_{2}
\end{array}\right]+\left[\begin{array}{cc}
0 & \tilde{b}_{12} \\
\tilde{b}_{21} & 0
\end{array}\right]\left[\begin{array}{l}
y_{1} \\
y_{2}
\end{array}\right]+\left[\begin{array}{l}
x_{1} \\
x_{2}
\end{array}\right]} \\
{\left[\begin{array}{l}
y_{1} \\
y_{2}
\end{array}\right]=\left[\begin{array}{cc}
\left(I-B_{11}\right)^{-1} & 0 \\
0 & \left(I-B_{22}\right)^{-1}
\end{array}\right]\left\{\left[\begin{array}{cc}
0 & \tilde{b}_{12} \\
\tilde{b}_{21} & 0
\end{array}\right]\left[\begin{array}{l}
y_{1} \\
y_{2}
\end{array}\right]+\left[\begin{array}{l}
x_{1} \\
x_{2}
\end{array}\right]\right\}} \\
\\
+\left[\begin{array}{l}
y_{1} \\
y_{2}
\end{array}\right]=\left[\begin{array}{cc}
0 & \left(I-B_{11}\right)^{-1} \tilde{b}_{12} \\
\left(I-B_{22}\right)^{-1} \tilde{b}_{21} & 0
\end{array}\right]\left[\begin{array}{l}
y_{1} \\
y_{2}
\end{array}\right] \\
+\left[\begin{array}{cc}
\left(I-B_{11}\right)^{-1} & 0 \\
0 & \left(I-B_{22}\right)^{-1}
\end{array}\right]\left[\begin{array}{l}
x_{1} \\
x_{2}
\end{array}\right]
\end{gathered}
$$

Defining $D_{i j}=\left(I-B_{i i}\right)^{-1} \tilde{b}_{i j}$

$$
\left[\begin{array}{l}
y_{1} \\
y_{2}
\end{array}\right]=\left[\begin{array}{cc}
I & -D_{11} \\
-D_{22} & I
\end{array}\right]\left[\begin{array}{l}
y_{1} \\
y_{2}
\end{array}\right]+\left[\begin{array}{cc}
\left(I-B_{11}\right)^{-1} & 0 \\
0 & \left(I-B_{22}\right)^{-1}
\end{array}\right]\left[\begin{array}{l}
x_{1} \\
x_{2}
\end{array}\right]
$$

or $\quad y=M_{r z} M_{r 1} x$

$M_{r z}$ is an 'inter-regional multiplier matrix' that captures all of the repercussions of spatial flows between the accounts of one region and those of the other. $M_{r 1}$, for one, is an 'intra-regional 
multiplier matrix' that shows the intra-regional multiplier effects resulting from linkages between the accounts in each separate sub-region.

Round (2003) decomposes the inter-regional multiplier matrix $M_{r z}$ as follows

$M_{r}=I+\left(M_{r 1}-I\right)+\left(M_{r 2}-I\right) M_{r 1}+\left(M_{r 3}-I\right) M_{r 2} M_{r 1}$

where $I$ is an initial injection, $\left(M_{r 1}-I\right)$ is net contribution of the transfer multiplier, $\left(M_{r 2}-I\right) M_{r 1}$ is net contribution of open loop or cross-multiplier effects, and $\left(M_{r 3}-I\right) M_{r 2} M_{r 1}$ is net contribution of circular or closed-loop effect.

$y=M_{r 3} M_{r 2} M_{r 1} x$

$\mathrm{M}_{\mathrm{r} 2}$ is an interregional 'open loop' multiplier matrix that captures the effect that one region has upon another after accounting for all 'own-region' effects. $M_{r 3}$ shows the impacts that pass through the accounts in the other region before returning to their "own region", thus showing the inter-regional feedback effects. The separation of these effects gives a picture of structural independences within the endogenous accounts of SAM.

\section{Multiplier analyses for South Ostrobothnia and North Karelia}

Three different indicators: output multipliers, induced factor income effects and household multipliers are calculated from the SAMs and reported below. These indicators can show the effects that changes in demand or income have, through the web of linkages, on the different actors of the economic system. The SAM output multiplier shows the total change in the value of output in the output of economy following a unit increase in final demand for a single sector's output. In addition to this, because the factors, firms and households are endogenous in the model, the SAM multiplier effects also show induced feedback effects resulting from the household re-spending. Hence, the model can simultaneously solve for the structure of production, the distribution, and the level of income in the economy (Roberts et al., 1999).

The SAM output multipliers of South Ostrobothnia and North Karlia are presented in Table 2. For example, multiplier value 2.580 for the rural food processing in South Ostrobothnia suggests that a EUR 1 million increase in demand for the rural food processing sector in South Ostrobothnia would result, in addition to the EUR 1 million increase in the rural food sector itself, in an additional increase of EUR 1.281 million in the output of all rural sectors, since the expansion of the rural food processing increases demand for inputs and services. In addition to the rural effects, the shock will increase industrial activity in the urban area of Seinäjoki by EUR 0.299 million.

A high multiplier value of a particular industry suggests that this industry has a strong potential for stimulating local economic activity due to the high amount of linkages it has to other local economic actors. Concerning both of the provinces, the highest aggregate multiplier values (i.e. multipliers include both rural and urban effects) were possessed by agriculture and rural and urban food industries. As for the rural areas, the highest multipliers in South Ostrobothnia were those of agriculture (2.36), rural food industry (2.28) and farm diversified activities (1.84). In rural North Karelia, the three highest multiplier values were possessed by the rural food industry (1.94) agriculture (1.92) and rural wood processing (1.69). The importance of forestry-related activities in North Karelia is visible in these values. As for the urban areas, in South Ostrobothnia the highest values were those of urban food manufacturing (1.30) hotels and catering (1.26) and other private services (1.22), and for the urban area of North Karelia Joensuu, the highest values were those of urban food manufacturing (1.42), urban construction (1.38) and urban hotels and catering (1.36). It is worth noting that rural industry output multiplier values were higher in South Ostrobothnia, while the multipliers generated by increases in demand of the products and services of urban industries were throughout higher in North Karelia. 


\begin{tabular}{|c|c|c|c|c|c|c|}
\hline & \multicolumn{2}{|c|}{ South Ostrobothnia } & \multirow[b]{2}{*}{ Urban } & \multicolumn{2}{|c|}{ North Karelia } & \multirow[b]{2}{*}{ Urban } \\
\hline & Aggregate & Rural & & Aggregate & Rural & \\
\hline A-Ragri & 2.722 & 2.361 & 0.361 & 2.413 & 1.924 & 0.489 \\
\hline A-Rdiversified & 2.094 & 1.840 & 0.253 & 1.862 & 1.514 & 0.348 \\
\hline A-RPrimary & 1.543 & 1.415 & 0.128 & 1.561 & 1.365 & 0.195 \\
\hline A-Rfood & 2.580 & 2.281 & 0.299 & 2.366 & 1.945 & 0.421 \\
\hline A-Rwood & 1.934 & 1.743 & 0.191 & 2.037 & 1.694 & 0.344 \\
\hline A-Rfuel & 1.664 & 1.501 & 0.162 & 1.840 & 1.496 & 0.344 \\
\hline A-Rmetal & 1.875 & 1.678 & 0.197 & 1.739 & 1.410 & 0.329 \\
\hline A-Renergy & 1.704 & 1.542 & 0.163 & 1.773 & 1.505 & 0.268 \\
\hline A-Roth manuf & 1.834 & 1.658 & 0.176 & 1.866 & 1.507 & 0.359 \\
\hline A-Rconstruction & 1.814 & 1.619 & 0.195 & 1.925 & 1.545 & 0.380 \\
\hline A-Rtrade & 1.681 & 1.499 & 0.182 & 1.762 & 1.426 & 0.336 \\
\hline A-Rhotels & 2.049 & 1.790 & 0.260 & 1.876 & 1.516 & 0.359 \\
\hline A-Rtransport & 1.512 & 1.372 & 0.140 & 1.610 & 1.342 & 0.268 \\
\hline A-Rprivat services & 1.858 & 1.627 & 0.231 & 1.739 & 1.410 & 0.329 \\
\hline A-Rpublic services & 1.710 & 1.517 & 0.193 & 1.726 & 1.397 & 0.329 \\
\hline A-UPrimary & 1.686 & 0.522 & 1.164 & & & \\
\hline A-Ufood & 2.582 & 1.282 & 1.300 & 2.363 & 0.943 & 1.420 \\
\hline A-Uwood & 1.912 & 0.721 & 1.191 & 2.022 & 0.679 & 1.343 \\
\hline A-Ufuel & 1.698 & 0.528 & 1.170 & 1.834 & 0.492 & 1.341 \\
\hline A-Utmetal & 1.874 & 0.678 & 1.196 & 1.739 & 0.410 & 1.329 \\
\hline A-Uenergy & 1.717 & 0.551 & 1.166 & 1.758 & 0.496 & 1.262 \\
\hline A-Uoth manufact & 1.843 & 0.664 & 1.179 & 1.860 & 0.503 & 1.357 \\
\hline A-Uconstruction & 1.820 & 0.624 & 1.197 & 1.923 & 0.544 & 1.379 \\
\hline A-Utrade & 1.691 & 0.507 & 1.185 & 1.752 & 0.421 & 1.331 \\
\hline A-Uhotels & 2.052 & 0.792 & 1.260 & 1.872 & 0.514 & 1.357 \\
\hline A-Utransport & 1.529 & 0.384 & 1.145 & 1.591 & 0.332 & 1.260 \\
\hline A-Uprivat services & 1.801 & 0.584 & 1.217 & 1.731 & 0.406 & 1.325 \\
\hline A-Upublic services & 1.717 & 0.522 & 1.195 & 1.718 & 0.392 & 1.326 \\
\hline
\end{tabular}

Tab 2. SAM output multipliers.

Economic 'leakages' from the urban areas to the rural areas were higher both in South Ostrobothnia and North Karelia compared to the leakages from the rural areas to the urban areas i.e. the share of multiplier induced in the other region was larger. This result implies that urban industries are more dependent on production factors and household demand from the rural area than rural industries are on urban demand and production factors. The most important reason for this is that the major urban manufacturing industries, for example the food industry, use rural production factors. In addition, a significant part of private services and distribution are concentrated in the urban areas.

Tables 3 and 4 present the factor income effects that a unit increase in final demand for a particular sector's output would generate. In South Ostrobotnia, the highest total factor income multipliers were possessed by agriculture, farm diversified activity and rural public services. By separating these multipliers, Table 3 shows that agriculture, other farm-related activities (diversified farms) and other private services generate the highest capital and land income effects in the rural area of South Ostrobothnia, whereas in the urban area of Seinäjoki, the urban primary sector (i.e. forestry and mining), urban transportation and other urban private services possess the highest values.

In North Karelia, the three top sectors measured by the aggregate factor multiplier values are agriculture, other farm-related activity and urban public services. The highest rural capital and 
land earnings are generated by agriculture, other farm-related activity and rural other primary activities (forestry and mining). The corresponding industries in the urban area of Joensuu are other urban private services, urban transportation and urban energy.

\begin{tabular}{|l|c|c|c|c|}
\hline & $\begin{array}{c}\text { Total } \\
\text { effect }\end{array}$ & $\begin{array}{c}\text { Rural capital and } \\
\text { land }\end{array}$ & $\begin{array}{c}\text { Urban capital and } \\
\text { land }\end{array}$ & $\begin{array}{c}\text { Employment } \\
\text { effect }\end{array}$ \\
\hline A-Ragri & $\mathbf{1 . 5 7 9}$ & $\mathbf{1 . 0 3 7}$ & 0.087 & 0.456 \\
A-Rdiversified & $\mathbf{1 . 2 1 6}$ & $\mathbf{0 . 8 2 2}$ & 0.062 & 0.331 \\
A-Rfood & 1.014 & 0.549 & 0.071 & 0.394 \\
A-Rwood & 0.808 & 0.383 & 0.059 & 0.367 \\
A-Rconstruction & 0.784 & 0.300 & 0.049 & 0.435 \\
A-Rtrade & 0.977 & 0.387 & 0.051 & 0.539 \\
A-Rhotels & 0.898 & 0.307 & 0.064 & 0.527 \\
A-Rtransport & 0.952 & 0.516 & 0.038 & 0.398 \\
A-Rprivat & & & 0.061 & 0.365 \\
services & 1.075 & 0.650 & 0.051 & 0.796 \\
A-Rpublic & & & 0.460 & 0.251 \\
services & $\mathbf{1 . 0 7 8}$ & 0.231 & 0.165 & 0.395 \\
A-UPrimary & 0.891 & 0.180 & 0.200 & 0.403 \\
A-Ufood & 1.016 & 0.455 & 0.195 & 0.436 \\
A-Uwood & 0.828 & 0.225 & 0.293 & 0.541 \\
A-Uconstruction & 0.787 & 0.156 & 0.140 & 0.402 \\
A-Utrade & 0.982 & 0.148 & 0.447 & 0.423 \\
A-Uhotels & 0.899 & 0.231 & 0.436 & $\mathbf{0 . 7 9 1}$ \\
A-Utransport & 0.960 & 0.112 & 0.131 & \\
A-Uprivat & & & & \\
services & 1.028 & 0.170 & & \\
A-Upublic & & 0.153 & & \\
services & 1.075 & & & \\
\hline
\end{tabular}

Tab 3. Factor income effects in South Ostrobothnia.

The highest figures for labour income were generated by rural and urban public services and urban trade. This result is reasonable due to the high labour intensity of these sectors. The labour income in the SAM presents the wages and salaries paid to employees. According to Roberts et al. (1999), employment effects measure the amount of employment generated in the whole economy as a result of a unit increase in demand for output from a particular sector. For example, a EUR 1 million increase in demand for urban public services in North Karelia leads to the total increase of wages and salaries of the whole region of EUR 0.795 million.

Table 5 presents the SAM household multipliers that measure the total effect of a unit change in income of a particular household group on the incomes of all households in the economy. This effect might be brought by a change, for example, in the income tax regime, or a change in value of transfer earnings from outside the region. The results indicate that, for example, an increase of EUR 1,000 in the income of rural commuter households in South Ostrobothnia would increase the income of all the households in South Ostrobothnia EUR 1,290. 


\begin{tabular}{|c|c|c|c|c|}
\hline & $\begin{array}{l}\text { Total } \\
\text { effect }\end{array}$ & $\begin{array}{l}\text { Rural capital and } \\
\text { land }\end{array}$ & $\begin{array}{l}\text { Urban capital and } \\
\text { land }\end{array}$ & $\begin{array}{c}\text { Employment } \\
\text { effect }\end{array}$ \\
\hline A-Ragri & 1.502 & 0.907 & 0.133 & 0.462 \\
\hline A-Rdiversified & 1.081 & 0.640 & 0.102 & 0.338 \\
\hline A-RPrimary & 1.037 & 0.746 & 0.059 & 0.233 \\
\hline A-Rfood & 0.933 & 0.424 & 0.114 & 0.395 \\
\hline A-Renergy & 0.897 & 0.529 & 0.083 & 0.286 \\
\hline A-Rconstruction & 0.787 & 0.182 & 0.099 & 0.506 \\
\hline A-Rtrade & 0.960 & 0.324 & 0.103 & 0.534 \\
\hline A-Rhotels & 0.848 & 0.236 & 0.101 & 0.511 \\
\hline $\begin{array}{l}\text { A-Rtransport } \\
\text { A-Rprivat }\end{array}$ & 0.984 & 0.500 & 0.079 & 0.405 \\
\hline $\begin{array}{l}\text { services } \\
\text { A-Rpublic }\end{array}$ & 1.018 & 0.522 & 0.097 & 0.399 \\
\hline services & 1.064 & 0.187 & 0.099 & 0.778 \\
\hline A-Ufood & 0.931 & 0.354 & 0.183 & 0.394 \\
\hline A-Uenergy & 0.888 & 0.195 & 0.411 & 0.282 \\
\hline A-Uconstruction & 0.786 & 0.135 & 0.145 & 0.506 \\
\hline A-Utrade & 0.955 & 0.119 & 0.304 & 0.531 \\
\hline A-Uhotels & 0.846 & 0.146 & 0.190 & 0.510 \\
\hline $\begin{array}{l}\text { A-Utransport } \\
\text { A-Uprivat }\end{array}$ & 0.974 & 0.090 & 0.483 & 0.400 \\
\hline $\begin{array}{l}\text { services } \\
\text { A-Upublic }\end{array}$ & 1.021 & 0.106 & 0.561 & 0.354 \\
\hline services & 1.079 & 0.108 & 0.175 & 0.795 \\
\hline
\end{tabular}

Tab 4. Factor income effects in North Karelia.

\begin{tabular}{lcccccc}
\hline & \multicolumn{3}{c}{ South Ostrobothnia } & \multicolumn{5}{c}{ North Karelia } \\
& All HHs & Rural HHs & Urban HHs & All HHs & Rural HHs & Urban HHs \\
\hline H-Agri & 1.322 & 1.253 & 0.068 & 1.267 & 1.173 & 0.094 \\
H-Rworking & 1.273 & 1.213 & 0.061 & 1.259 & 1.163 & 0.096 \\
H-Rother & 1.397 & 1.312 & 0.085 & 1.332 & 1.212 & 0.120 \\
H-Rcommuter & 1.290 & 1.226 & 0.064 & 1.259 & 1.164 & 0.095 \\
H-Uworking & 1.299 & 0.233 & 1.066 & 1.250 & 0.157 & 1.093 \\
H-Uother & 1.383 & 0.301 & 1.082 & 1.322 & 0.205 & 1.117 \\
H-Tourist & 0.344 & 0.269 & 0.076 & 0.329 & 0.216 & 0.113 \\
\hline
\end{tabular}

Tab 5. Household multipliers.

\section{Multiplier scenario analyses}

SAM multiplier analyses are interpreted here as economic scenarios. The effects of these scenarios will not appear immediately; rather the adjustments occur over time. Four different scenario analyses were carried out with the SAM multiplier model. These different analyses are directed towards the specific key sectors and policy measures that both academics and policy makers have often defined as important sectors and measures for the development of rural regions. The output multiplier analysis above showed that agriculture possessed the highest output and total factor income multipliers in both of the provinces. Therefore, and because agriculture is generally considered one of the major economic sectors in preserving livelihood in rural areas, two agricultural policy-related scenarios are performed. Hotels and catering were also among the sectors with the highest output multiplier values in both of the provinces. 


\section{Agricultural policy scenarios}

The first scenario presents a simultaneous cut in agricultural subsidies and the corresponding subsidy transfer to other farm-related activities. In Finland, due to the strong structural change, other farm-related economic activities, in addition to traditional agriculture, have become increasingly important for the rural areas of Finland. Farm accounting in 2000, for the first time, collected information on these business activities and their economic importance. According to TIKE (2006), the term 'diversified farm' refers to a farm that has other business activities in addition to agriculture or forestry. These can be, for example, food processing, tourism services and machinery contracting services. The farm structure studies of 2003 and 2005 (TIKE, 2004; TIKE, 2006) have collected further information on these farms. In 2005, there were 24,249 diversified farms in Finland of which 2,596 were located in South Ostrobothnia and 990 in North Karelia. The number of diversified farms both in 2003 and 2005 was the highest in South Ostrobothnia among all the Finnish NUTS3 regions.

In order to simulate the subsidy transfer from agriculture to other farm activities, an additional farm-related activity was included in the SAMs. Because the total output of these diversified activities on the province level is relatively small, not all the different industries or activities that the diversified farms are engaged in were included as such. Instead, a representative diversified activity was constructed so that in South Ostrobothnia, the activity consists of $26 \%$ of food manufacturing, $6 \%$ of trade, $17 \%$ of tourist services and $50 \%$ of business services. The corresponding structure in North Karelia is $19 \%$ of food manufacturing, $6 \%$ of trade, $19 \%$ of tourist services and $56 \%$ of business services. These shares and the activities reflect the actual farm accounting data collected from South Ostrobothnia and North Karelia so that the shares of manufacturing and services are equivalent, and the most important activities are included. The structures of the production processes were differentiated and the inputs and the input shares of the diversified activities differ from those of actual agriculture. In 2002, the total amount of the agricultural subsidy in South Ostrobothnia was EUR 192.6 million. Thus the 30\% cut in subsidies amounted to EUR 57.8 million. Correspondingly, the total amount of agricultural subsidy in North Karelia was EUR 70.8 million, and the $30 \%$ cut was EUR 21.24 million. For comparison, the second scenario presents a $10 \%$ increase in agricultural subsidies.

\section{Transportation investment and tourism scenarios}

The first two scenarios concentrated on the primary sector and thus they predominantly stimulate rural areas. The following scenarios consider the changes through tertiary sectors, i.e. transportation and infrastructure services and tourism.

Infrastructure affects the output of firms both directly and indirectly. A direct effect is that infrastructure serves as a priced or non-priced input in production. Indirect effects occur when infrastructure interacts with other inputs and affects their productivity, or when it serves as an amenity that increases the supply of other inputs (Immergluck, 1993). Transportation costs are one of the major factors directing the location decisions of enterprises, and determining how enterprises, especially in remote rural areas, will thrive in the long run. In sparsely-populated Finland, the operation of transportation systems is particularly important since distances are long both within the country and to the core market areas in Europe.

In the Social Accounting Matrices each transportation activity summarises the transactions of transportation, telecommunication, postal services and travel agency services. The transportation sectors comprise $7.5 \%$ of the regional GDP and $5.6 \%$ of the regional employment in South Ostrobothnia. The corresponding figures for North Karelia are $8.2 \%$ and $6 \%$, respectively. The third simulation outlines the impacts of a $10 \%$ increase in investments of transportation and infrastructure. Since the investments in the SAMs are measured in commodities, the extra injection is not allocated to either rural or urban transportation activities, but rather to the overall investments of transportation and infrastructure building and services. The regional investments in the base year SAMs are presented in Table 6.

The importance of the tourist industry is recognised as an important source and potential for rural development in Finland (Rural Policy Committee, 2009). Finnish nature and nature-related activities are the most important attractions for foreign visitors. The major weaknesses of 
the Finnish tourist industry are the heterogeneity of entrepreneur skills, and the weak command of customer services and processes. In addition, marketing, networking and product development are the weak spots of the industry (Ministry of Trade and Industry, 2006). Investment in the development of tourism is one of the future strategies in both the study regions. According to the Regional Council of North Karelia (2007), the strengths of local tourist services are hospitality, local arts and crafts and natural attractions. In addition, the growing number of Russian tourists is a future opportunity. As for South Ostrobothnia, tourism has substantially diversified during the early 2000s. Though the region has not traditionally been a well-known tourist area, local traditions and agricultural landscapes are undisputed potential especially for Finnish travellers (Seinäjoki University of Applied Sciences 2007).

The fourth scenario, the increase in tourism demand, was modelled by increasing the income of the tourist households by $10 \%$. These household groups represent tourism coming from outside of the provinces, i.e. tourists from the other Finnish provinces and from foreign countries. In the SAMs, tourist households earn their income from the rest of the world account. Thus, in the multiplier analysis, the exogenous injection of tourism is allocated straight to a specific household group instead of subsidising tourism-related industries. The consumption structures of the tourist households were drawn from the Tourist Satellite Accounts of Statistics Finland and are presented in Table 6.

\begin{tabular}{|c|c|c|c|c|c|c|c|c|}
\hline & \multicolumn{4}{|c|}{ South Ostrobothnia } & \multicolumn{4}{|c|}{ North Karelia } \\
\hline & \multicolumn{2}{|c|}{ Tourism demand } & \multicolumn{2}{|c|}{ Investments } & \multicolumn{2}{|c|}{ Tourism demand } & \multicolumn{2}{|c|}{ Investments } \\
\hline & Mill $€$ & $\%$ & Mill $€$ & $\%$ & Mill $€$ & $\%$ & Mill $€$ & $\%$ \\
\hline C-agri & 1.19 & 1.96 & -0.42 & -0.06 & 1.14 & 1.92 & -0.52 & -0.08 \\
\hline C-forest & 0.25 & 0.41 & 3.64 & 0.51 & 0.25 & 0.41 & 3.88 & 0.62 \\
\hline C-fish & 0.05 & 0.08 & 0.01 & 0.00 & 0.07 & 0.12 & 0.00 & 0.00 \\
\hline C-mining & 0.00 & 0.00 & 2.46 & 0.34 & 0.00 & 0.00 & 1.86 & 0.30 \\
\hline C-food & 3.23 & 5.30 & -0.03 & 0.00 & 3.44 & 5.77 & -0.25 & -0.04 \\
\hline C-textile & 0.86 & 1.41 & 2.06 & 0.29 & 0.79 & 1.33 & 1.97 & 0.31 \\
\hline C-timber & 0.01 & 0.02 & -1.05 & -0.15 & 0.03 & 0.04 & -1.58 & -0.25 \\
\hline C-paper & 1.06 & 1.74 & 9.15 & 1.27 & 1.10 & 1.85 & 7.00 & 1.11 \\
\hline C-fuel & 1.21 & 2.00 & 1.96 & 0.27 & 7.24 & 12.12 & 1.50 & 0.24 \\
\hline C-mineral & 0.05 & 0.09 & 0.26 & 0.04 & 0.07 & 0.11 & 0.19 & 0.03 \\
\hline C-metal & 0.05 & 0.08 & 5.37 & 0.75 & 0.07 & 0.11 & 5.24 & 0.83 \\
\hline C-machinery & 0.35 & 0.57 & 58.87 & 8.19 & 0.47 & 0.78 & 59.66 & 9.46 \\
\hline C-electronic equipment & 0.77 & 1.26 & 82.34 & 11.46 & 0.69 & 1.15 & 83.96 & 13.32 \\
\hline C-Tranportation equipment & 1.06 & 1.75 & 26.21 & 3.65 & 1.66 & 2.78 & 27.08 & 4.30 \\
\hline C-other manufacturing & 0.44 & 0.72 & 3.49 & 0.49 & 0.52 & 0.87 & 3.52 & 0.56 \\
\hline C-energy & 0.00 & 0.00 & 0.00 & 0.00 & 0.00 & 0.00 & 0.00 & 0.00 \\
\hline C-construction & 0.00 & 0.00 & 402.93 & 56.07 & 0.00 & 0.00 & 325.24 & 51.58 \\
\hline C-trade & 12.18 & 20.02 & 10.61 & 1.48 & 4.64 & 7.78 & 10.67 & 1.69 \\
\hline C-hotels and catering & 17.77 & 29.19 & 0.00 & 0.00 & 17.41 & 29.16 & 0.00 & 0.00 \\
\hline C-transport & 16.53 & 27.16 & 0.99 & 0.14 & 14.64 & 24.53 & 0.88 & 0.14 \\
\hline C-banking & 0.00 & 0.00 & 0.00 & 0.00 & 0.00 & 0.00 & 0.00 & 0.00 \\
\hline C-business services & 0.00 & 0.00 & 102.57 & 14.27 & 1.47 & 2.47 & 92.51 & 14.67 \\
\hline C-estate & 0.00 & 0.00 & 0.00 & 0.00 & 0.00 & 0.00 & 0.00 & 0.00 \\
\hline C-public services & 0.00 & 0.00 & 0.00 & 0.00 & 0.00 & 0.00 & 0.00 & 0.00 \\
\hline C-education & 0.00 & 0.00 & 0.00 & 0.00 & 0.00 & 0.00 & 0.00 & 0.00 \\
\hline C-health services & 0.00 & 0.00 & 0.00 & 0.00 & 0.00 & 0.00 & 0.00 & 0.00 \\
\hline C-other services & 3.80 & 6.24 & 7.14 & 0.99 & 3.99 & 6.68 & 7.71 & 1.22 \\
\hline Total & 60.87 & 100.00 & 718.55 & 100.00 & 59.68 & 100.00 & 630.52 & 100.00 \\
\hline
\end{tabular}

Tab 6. Tourism demand and investments. 


\section{Scenario results}

Figure 1 illustrates the percentage changes in the aggregate outputs, produced by the multiplier scenarios, by provinces and by rural and urban areas. Measures directed towards agricultural activities had relatively stronger impacts in South Ostrobothnia, while the impacts of the infrastructure and tourism shocks were stronger in North Karelia. When comparing the rural and urban areas, transportation and tourism especially benefited the urban area of South Ostrobothnia, while in North Karelia the infrastructure investments were more favourable for the rural area.

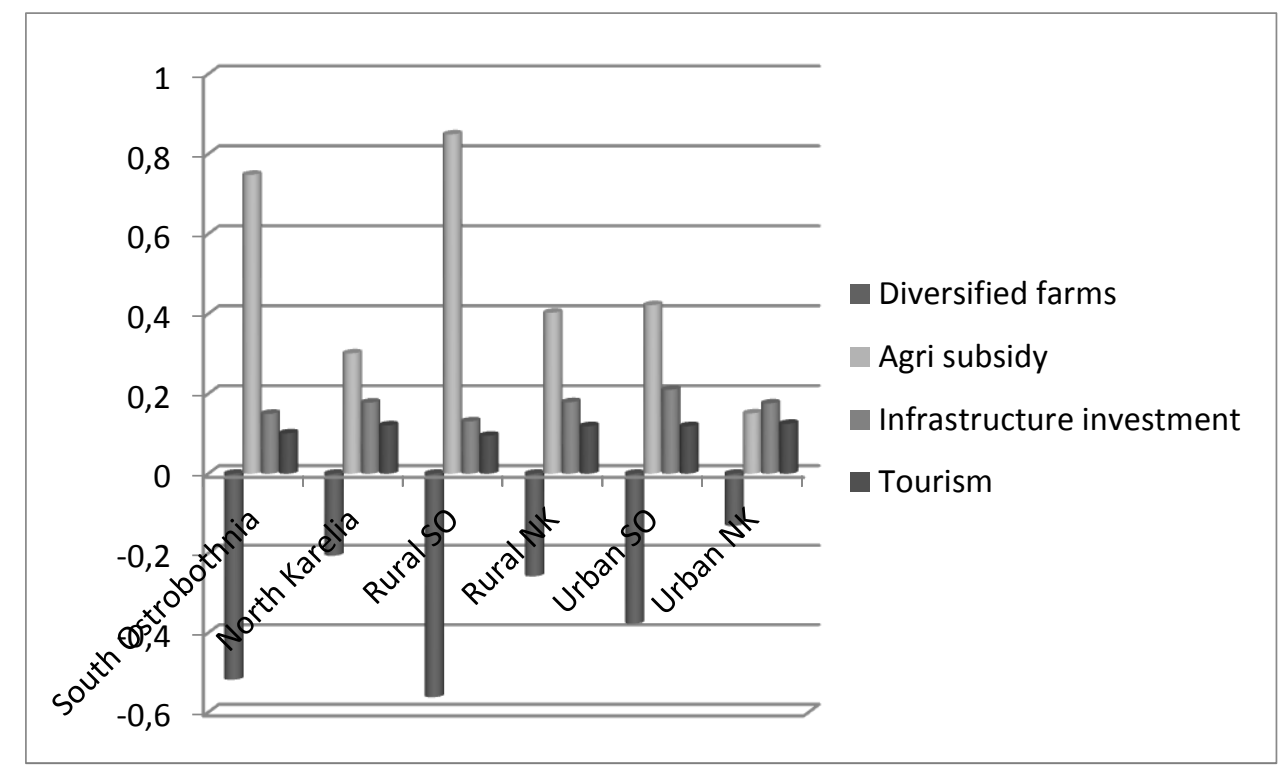

Fig 1. Percentage changes of the aggregate outputs.

In South Ostrobothnia, a EUR 57.8 million cut in agricultural support from traditional agriculture and transfer to diversified activity caused a EUR 68.97 million decrease in agricultural output and simultaneously, a EUR 54.95 million increase in the output of diversified activity. The corresponding figures for North Karelia were 25.17 and 20.71 million EUR. The total changes in both of the provinces were negative, however small. One explanation for this result can be found from the output multiplier values presented above. The analysis showed that the output and factor income multipliers of agriculture were bigger in both of the regions compared with those of the diversified activities. These multiplier values reflect the ability of a certain activity to stimulate local economic activity due to its economic linkages. Hence, the results suggest that traditional agriculture can generate extra income more efficiently due to its linkages, and is thus able to use the income subsidies more efficiently compared with other farm-related activities. However, it is worth remembering that the multiplier analysis does not allow price changes or factor movements.

In contrast, a EUR 19.26 / 7.08 million increase in agricultural subsidy in South Ostrobothnia / North Karelia generated a EUR 52.43 / 17.09 million increase in the (regional) total output. Since only 25.7 / 9.04 million of this output increase originated from agriculture, the results suggest that agricultural subsidy is able to generate substantial positive spillover effects in these rural regions. The extra agricultural support benefited not only the other rural industries, but also the urban industries through the rural-urban linkages.

In South Ostrobothnia, infrastructure investment of EUR 10.640 million increased the regional total output by EUR 10.49 million, of which rural output accounted for $67 \%$. Industries that benefited most from the transportation infrastructure investment, in addition to the transportation industries, were rural and urban fuel, trade, and hotel and catering activities. In North Karelia, a EUR 8.229 million injection increased the regional total output by EUR 10.087 million, of which rural output accounted for $60 \%$. The greatest beneficiaries were transportation, trade, hotel and catering, and other private services. In South Ostrobothnia, increase in tourism demand for local goods and services of EUR 6.087 million increased the regional total output by 
EUR 7.045 million and in North Karelia, a tourism injection of EUR 5.968 million increased the regional total output by EUR 6.884 million. Trade, hotels and catering, transportation and other private services were the industries that gained the most. Since diversified activity also includes tourism it earned extra income.

Figures 2 and 3 further illustrate the differences between the study provinces showing that the changes in agricultural subsidies particularly affected capital and land rents. This suggests that income subsidies tend to capitalise in agricultural land prices as, for example, Swinbank and Tranter (2004) have previously suggested. As a consequence of increased infrastructure investments, total factor earnings increased by EUR 6.498 million in South Ostobothnia and EUR 6.108 million in North Karelia. As a result of the tourism scenario, the factor earning increased EUR 3 million in both of the provinces.

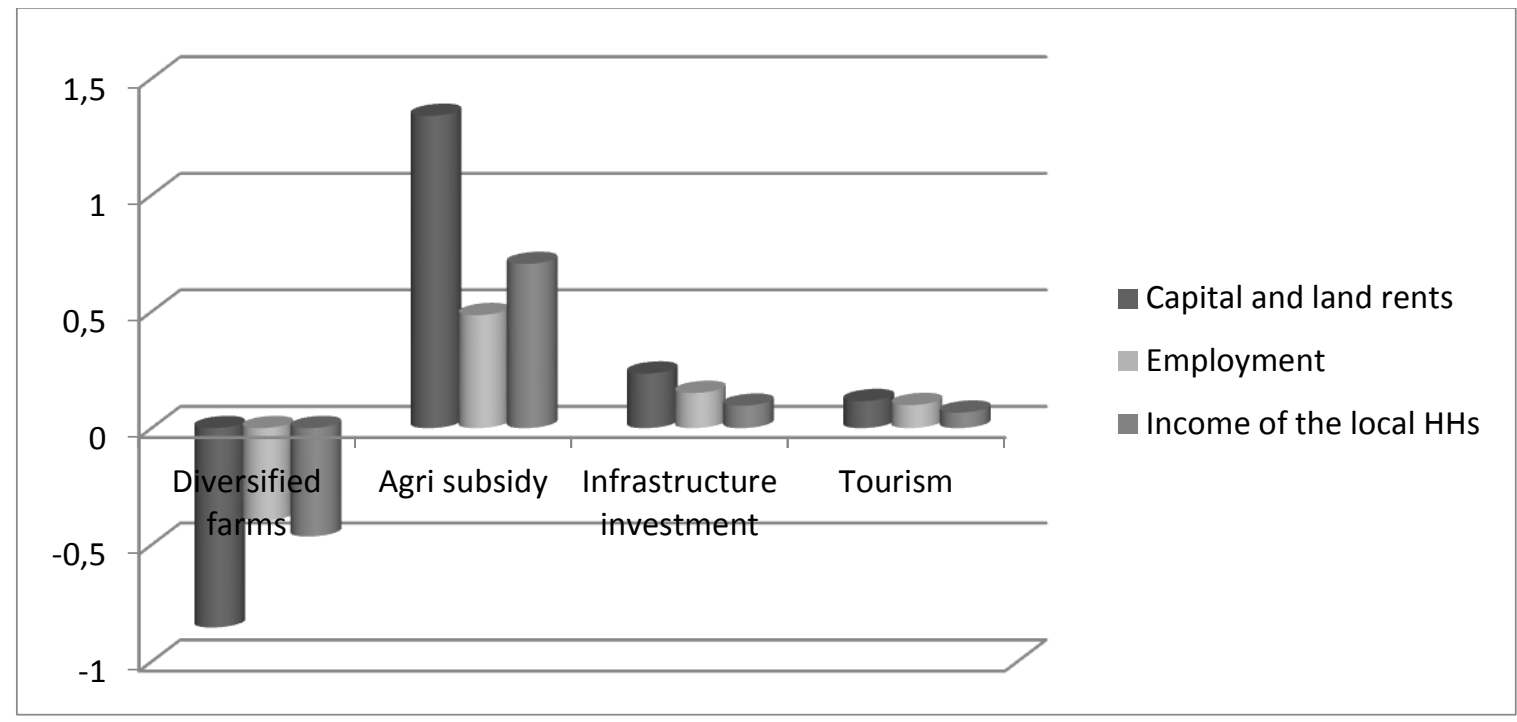

Fig 2. South Ostrobothnia, employment, capital and household income, \% changes.

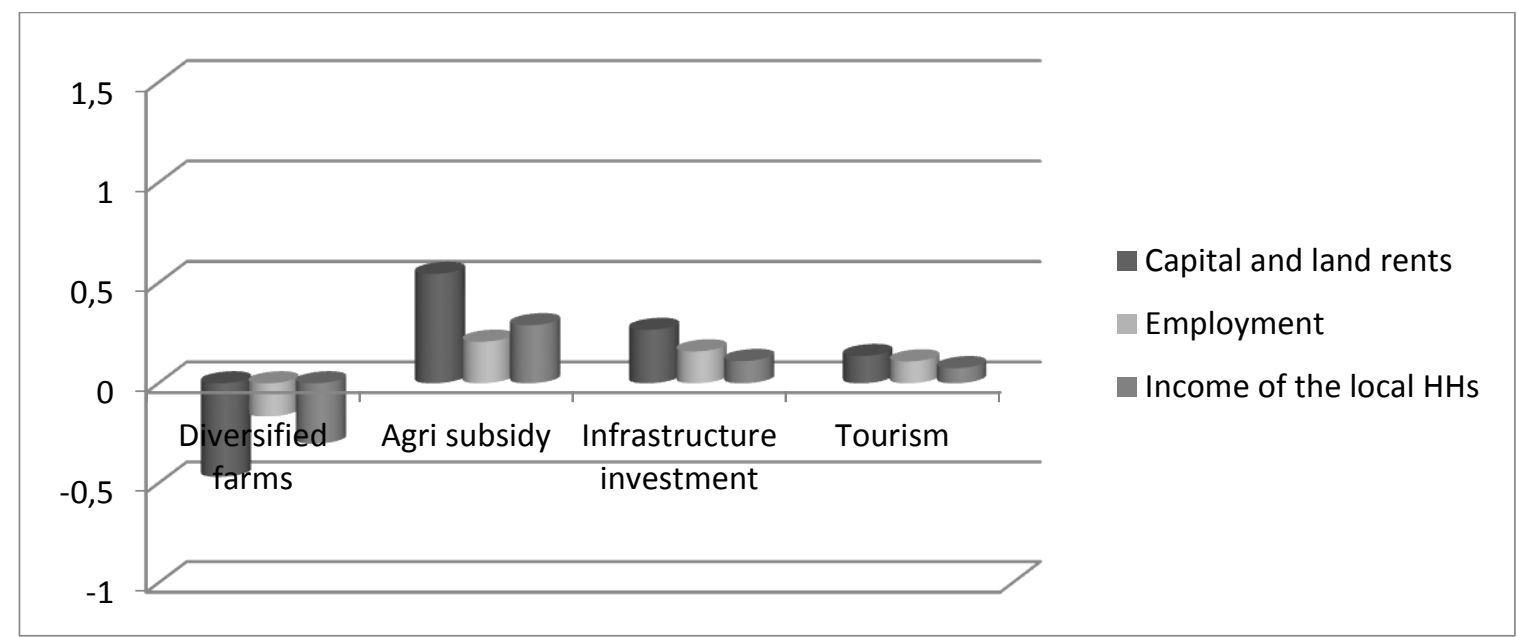

Fig 3. North Karelia, employment, capital and household income, \% changes.

When looking at the impacts on household incomes, the relative percentage changes were larger compared with the changes in terms of activity outputs, the major factor being changes in agricultural household incomes. In the diversified farm scenario, agricultural households in North Karelia lost more than agricultural households in South Ostrobothnia. Partly, this is due to the differences in the industrial structures of the diversified farms of the regions. In addition in South Ostrobothnia, a significantly larger part of the agricultural household income already comes from diversified activities. It is worth noticing that rural and urban household groups earn factor incomes also crosswise from rural and urban industries. Due to this fact and to changes in household expenditures, impacts drift to all the household groups through a complex web of linkages. Transport investment benefited especially the working households, and commuters 
and urban household gained the most. Exogenous increase in tourism generated extra income also for the local households and, as expected, the working households benefited most. Appendices 2 and 3 display the impacts of the different scenarios on outputs, capital rents, employment, and household incomes in euro and in percentages.

\section{Discussion}

The output multiplier values demonstrate the still important role of agriculture and food manufacturing in both provinces. In the urban areas, however, services and construction were among the industries which possessed the highest income generating potential through economic linkages. In general, the output multipliers in both provinces were relatively low, indicating that these provinces are relatively open economies. This implies that the links to the rest of the country are important.

In comparison with the previous SAM multiplier study (Kola and Nokkala, 1999) of these provinces concerning the base year 1995, the multipliers presented above are significantly lower. The former study reported output multiplier values that ranged from 4.92 for construction to 10.54 for food manufacturing in North Karelia, and from 3.57 for pulp and paper to 8.65 for food production in South Ostrobothnia. The earlier study, however, concerned the provinces as a whole, and therefore could not show rural-urban linkages within the provinces. Compared with other European, rural-urban multiplier studies, the magnitude of the multipliers of this study are more equal. Roberts' (1998) analysis of Grampian Scotland (base year 1989), Psaltopoulos' et al. (2006) analyses of Archanes, Nikos Kazantzakis and Heraklion in Greece (base 1998) reported aggregate output multiplier values ranging from 1.52 to 2.71 in Greece and from 1.00 to 2.07 in Scotland. The results suggest that these Finnish provinces have been closed economies compared with these other European 'remote' regions. However, these Finnish provinces have recently become more open and more linked with the rest of the country and the rest of the world. During the period 1995-2002, Finland became a member of the European Union and the economic structures of the study provinces have changed so that services and manufacturing have become relatively more important.

In this study, the urban and rural industries, for example the food industries, had almost an equal potential for stimulating the whole economies of South Ostrobothnia and North Karelia. Yet, urban industries generated significantly larger effects on the rural areas (through interregional linkages) than vice versa. The explanation for this is the reliance of urban activities on the inputs and factors from rural industries and households, and the dependence on rural household demand. This latter result corresponds to the findings of Roberts (1998). In rural areas the primary sectors generated the highest capital and land factor incomes, whereas in the urban areas, transportation was among the most important industries in terms of land and capital incomes. In contrast, rural and urban public services and urban trade (distribution) generated the greatest labour income effects. The latter can be traced back to the high labour intensity of these services.

The household multiplier values suggest that, after taking account of all the linkages and interdependencies, an extra income allocated to the low income households, i.e. pensioners, unemployed and students, would generate a higher overall increase in incomes of households if compared to the situation when the corresponding income transfer would have been allocated to working (higher income) households. This result is consistent with previous SAM-multiplier studies (Roberts, 1998; Psaltopoulos et al., 2006). This is reasonable, since poor households typically tend to consume their extra income, while wealthier households have a higher propensity to save. When comparing the income-generating potential of the rural households with the urban households in North Karelia, rural households have a higher potential than their urban peers. In contrast in South Ostrobothnia, the income-generating potential varies among the household groups. Therefore, it was not possible to draw a conclusion whether the rural or the urban households would possess higher income-generating potential.

Four different SAM multiplier scenario analyses were employed in order to investigate the potential of the different economic shocks entering the local economies through agriculture, transportation and tourism industries. Previously, in order to outline the networks of economic 
linkages in these regions, output, factor income and household multipliers were derived. Roberts (1998) argues that "the high multiplier values can be interpreted such that the sectors with the highest values are key sectors, where investment would induce, through the linkages, the greatest benefits for the whole area". Without dispute, agriculture, diversified activity and hotels and catering were among the industries possessing the highest multiplier values in both of the study regions. In contrast, the multiplier values of transportation were among the lowest. However, transportation infrastructure industries have other important qualities to offer, such as its ability to help overcome the drawbacks caused by remoteness. Not surprisingly, infrastructure investments have become an important policy instrument in improving competitiveness and reducing regional disparities both in Finland and in the European Union (European Commission, 2007, 2008). Therefore, it was reasonable to include the transport infrastructure scenario in this study.

North Karelia was more responsive to both the transportation and the tourism injections, whereas the agricultural injections resulted in greater changes in South Ostrobothnia. The relative importance of the different activities and also the relative importance of rural as opposed to urban economies are reflected in these results. Even if the absolute values of the injections were small in relation to the whole economies, these scenarios, excluding the agricultural subsidy transfer to the diversified farm activities, generated positive impacts clearly exceeding the values of expenditures allocated to these measures. Increase in agricultural support generated significant increases in the outputs of the other industries due to the high level of linkages. This support benefited not only rural areas but the positive impacts were also carried to the urban industries and households through the factor earnings and increased demand.

The limitations and drawbacks of the SAM multiplier analysis are well known and have been reported (e.g. Sadoulet and de Janvry, 1995; Round, 2003). Since the capacity constraints are neglected, the multiplier analysis tends to overestimate the total effects. This total response is also overestimated, because substitution effects are not allowed due to fixed prices. In practice, price changes would offset excess demand (supplies) in any of the markets and thus mitigate the total effects. However, the fact that the accounts are divided into endogenous and exogenous may cause both overestimation and underestimation of the effects, since part of the endogenous responses are absent. For example, changes in government expenditures and trade balances resulting from the injections would not be fed back into the system.

Comparison of various policy simulations both from province to province and from rural to urban area indicated that the magnitudes of the effects were area specific. In South Ostrobothnia, where food production and manufacturing are important, the agriculture-related policies generated more significant impacts compared with North Karelia, a rural region having a more heterogeneous economic structure. Indicatively, North Karelia was more responsive towards the infrastructure-transportation and tourism policies. In addition to the diverse economic structures, there are other area-specific features that may validate the different results. Polarisation of population and economic activity is characteristic of North Karelia. Although Joensuu is a relatively prosperous area, rural North Karelia, excluding the countryside near the urban area, suffers from outmigration and economic degradation. In contrast, both the population and the economic activity are rather evenly scattered throughout South Ostrobothnia. Therefore, compared with North Karelia, the relative distances are shorter and the region is more homogenous. The importance of the service sectors for the rural areas is highlighted by Bryden and Bollman (2000) and Rizov (2004). Tourism is the service often referred to in the rural development context. The tourism policy simulations resulted in growing regional income and employment for South Ostrobothnia and North Karelia, a result that coincides with the findings concerning Scotland (Blake et al. 2006). However, increased tourism incomes tend to be generated in urban areas.

Theories of regional development provide explanations for the undeniable strength of the urban areas. Knowledge spillovers, backward and forward linkages, the advantages of thick markets for specialised skills and economies of scale are defined as sources of agglomeration economies (Marshall, 1922; Fujita and Krugman, 2004). Notwithstanding that the theory of agglomeration classifies linkages as agglomerating sources, the consideration of agglomeration 
and dispersion through rural-urban linkages within a rural region offers perspective to a micro or "meso" level. The multiplier output analysis results indicated that urban activities spill over welfare to the surrounding rural areas. Accordingly, strong linkages do not exclusively accelerate agglomeration, in fact, quite the contrary. This finding coincides with Roberts (1998). Further, Henry et al. (1997) argue that if rural-urban linkages are strong and if urban growth causes positive spillover effects, a regional approach to development would be appropriate for rural areas.

The valuation of the results is dependent on the policy objectives. If the goal is to strengthen the overall regional development, the regional approach, i.e. accepting that urban areas are the engines of development, would be preferable since the urban areas are able to spill over benefits to the rural surroundings, as was also found in some previous studies (Henry et al., 1997; Durandon and Puga, 2002; Partridge et al., 2008). However, the drawback of these measures is the further concentration of economic activity and the population in urban centres. On the other hand, if the policy goal is to support the genuinely rural areas in these regions, more targeted, rural-specific measures are needed. Thus, knowledge of the specific features of the target areas is essential, since the same policy measures might have different effects depending on the economic structures of the region. This finding highlights the role of local actors.

\section{Acknowledgements}

The Finnish Cultural Foundation and the Finnish Cultural Foundation, South Ostrobothnia Regional fund have supported the completion of this paper. I thank Jukka Kola, Heikki Lehtonen and William Meyers and two anonymous reviewers for their helpful comments and suggestions.

References

[1] Assembly for European Regions (2010). Cohesion in Europe: Regions take up the challenge. Strasbourg.

[2] Baldwin, R., Forslid, R., Martin, P., Ottaviano, G. \& Robert-Nicoud, F. (2003). Economic Geography and Public Policy. Princeton University Press (NJ).

[3] Balkhausen, O., Banse, M. \& Grethe, H. (2008). Modelling CAP Decoupling in the EU: A Comparison of Selected Simulation Models and Results. Journal of Agricultural Economics 59(1), 57-71. Doi: 10.1111/j.1477-9552.2007.00135.x.

[4] Blake, A., Sinclair, M. T. \& Campos Soria, J. A. (2006). Tourism Productivity. Evidence from the United Kingdom. Annals of Tourism Research 33(4), 1099-1120. Doi: 10.1016/j.annals.2006.06.001.

[5] Boldrin, M \& Canova, F. (2001). Inequality and Convergence in Europe's Regions: Reconsidering European Regional Policies. Economic Policy 16(32), 207-253. Doi: 10.1111/1468-0327.00074.

[6] Bryden, J. \& Bollman, R. (2000). Rural employment in industrialised countries. Agricultural Economics 22(2), 185-197. Doi: 10.1111/j.1574-0862.2000.tb00017.x.

[7] Daniel, K. \& Kilkenny, M. (2009). Agricultural Subsidies and Rural Development. Journal of Agricultural Economics 60(3), 504-529. Doi: 10.1111/j.1477-9552.2009.00214.x.

[8] Durandon, G. \& Puga, D. (2002). From sectoral to functional urban specialization. Working Paper 9112. Cambridge (MA). National Bureau of Economic Research.

[9] European Commission (2007). Growing Regions, Growing Europe: Fourth Report on Economic and Social Cohesion. Brussels: European Commission.

[10] European Commission (2008). Green Paper on Territorial Cohesion: Turning Territorial Diversity into Strength. COM 616 final. Brussels: European Commission. 
[11] Fujita, M. \& Krugman, P. (2004). The New Economic Geography: Past, Present and the Future. Papers in Regional Science 83(1), 139-164. Doi: 10.1007/s10110-003-0180-0.

[12] Henry, M. S., Barkley, D. L. \& Bao, S. (1997). The hinterland's stake in metropolitan growth: evidence from selected southern regions. Journal of Regional Science 37(3): 479501. Doi: 10.1111/0022-4146.00065.

[13] Immergluck, D. (1993). The role of public infrastructure in urban economic development. Economic Development Quarterly 7(3), 310-18. Doi: 10.1177/089124249300700309.

[14] Kilkenny, M. (1993). Rural/Urban effects of Terminating Farm Subsidies. American Journal of Agricultural Economics. 75(4), 968-980. Doi: 10.2307/1243984.

[15] Kilkenny, M. (1998). Transport Costs and Rural Development. Journal of Regional Science 38(2), 293-312. Doi: 10.1111/1467-9787.00093.

[16] Kola, J. \& Nokkala, M., eds. (1999). Structural Policy Effects in Finnish Rural Areas: A Quantitative Social Accounting Matrix Approach. University of Helsinki. Department of Economics and Management. Publications no 23. Helsinki: University Press.

[17] Kortesluoma, A. (2007). Etelä-Pohjanmaan matkailustrategia ja toimintasuunnitelma vuosille 2007-2013. Seinäjoki: University of Applied Sciences.

[18] Kraybill, D. S. \& Dorfman, J. H. (1992). A Dynamic Intersectoral Model of Regional Economic Growth. Journal of Regional Science 32(1), 1-17. Doi: 10.1111/j.14679787.1992.tb00165.x.

[19] Marshall, A. (1922). Principles of Economics: an introductory volume. London: Macmillan.

[20] Ministry of Agriculture and Forestry (2007). Rural Development Programme for the Mainland Finland 2007-2013. Helsinki: Ministry of Agriculture and Forestry.

[21] Ministry of Trade and Industry (2006). Suomen matkailustrategia vuoteen 2020 and Toimenpideohjelma vuosille 2007-2013. The official Travel Site in Finland. Accessed on http://www.visitfinland.com.

[22] Mulligan, G. F. (1984). Agglomeration and Central Place Theory: A Review of the Literature. International Regional Science Review 9(1), 1-42. Doi: 10.1177/016001768400900101.

[23] Partridge, M. D., Rickman, D. S., Ali, K. \& Olfert, M. R. (2008). Lost in Space: Population Dynamics in the American Hinterlands and Small Cities. Journal of Economic Geography 8(6), 727-757. Doi: 10.1093/jeg/lbn038.

[24] Psaltopoulos, D., Balamou, E. \& Thomson, K. J. (2006). Rural-Urban impacts of CAP Measures in Greece: An Inter-regional SAM Approach. Journal of Agricultural Economics 57(3), 441-458. Doi: 10.1111/j.1477-9552.2006.00059.x.

[25] Puga, D. (2002). European regional policies in light of recent location theories. Journal of Economic Geography. 2(4), 373-406. Doi: 10.1093/jeg/2.4.373.

[26] Pyatt, G., \& Round, J. I., eds. (1985). Social Accounting Matrix: A basis for planning. Washington (DC): World Bank.

[27] Regional Council of North Karelia (2007). Pohjois-Karjalan matkailustrategia. Joensuu: Pohjois-Karjalaanmaakuntaliitto.

[28] Rizov, M. (2004). Rural Development and Welfare Implications of CAP Reform. Journal of Policy Modelling 26(2), 209-222. Doi: 10.1016/j.jpolmod.2004.03.003.

[29] Roberts, D. (1998). Rural-urban interdependencies: Analysis using an interregional SAM model. European Review of Agricultural Economics 25(4), 506-527. Doi: 10.1093/erae/25.4.506.

[30] Roberts, D., Thomson, K. J. \& Snowdon, P. (1999). Modelling the Western Isles Economy: Regional Accounts 1997. Aberdeen: Macaulay Land Use Research Institute. 
[31] Robinson, S., Cattaneo, A. \& El-Said, M. (2000). Updating and estimating a Social Accounting Matrix using cross entropy method. TMD discussion papers 59. Washington (DC): International Food Policy Institute.

[32] Round, J. I. (1985). Decomposing Multipliers for Economic Systems Involving Regional and World Trade. The Economic Journal. 95(378), 383-399.

[33] Round, J. (2003). Social Accounting Matrices and SAM-Based Multiplier Analysis in Tool Kit; Poverty and Social Impact Analysis. Washington (DC): World Bank.

[34] Rural Policy Committee (2009). Countryside for Vigorous Finland. Government Report to Parliament on Rural Policy. Rural Policy Committee publications 10/2009. Sastamala: Vammalan Kirjapaino.

[35] Sadoulet, E. \& de Janvry, A. (1995). Quantitative Development Policy Analysis. Baltimore: Johns Hopkins Press.

[36] Shankar, R. \& Shah, A. (2009). Lessons from European Union Policies for Regional Development. Policy Research Working Paper 4977. Washington (DC): The World Bank.

[37] Statistics Finland (2006). Regional Input Output tables. Available at http://pxweb2.stat.fi/database/StatFin/kan/apt/apt_fi.asp.

[38] Statistics Finland (2007). Virtual Statistics. Toimialaluokitus TOL 2002.

[39] Statistics Finland (2009). Regional Accounts. Available at: http://www.stat.fi/til/altp/tau.html.

[40] Swinbank, A. \& Tranter, R. (2004). A Bond Scheme for Common Agricultural Policy Reform. Wallingford: CABI Publishing.

[41] Thomson, K., Berkhout, P. \& Constantinou, A. (2010). Balancing between structural and rural policy. In: Oskam, A., Meester, G. \& Silvis, H., eds., EU Policy for Agriculture, Food and Rural Areas. Wageningen Academic Publishers.

[42] TIKE (2004). Maatalouden rakennetutkimus 2003, Maatilojen muu yritystoiminta. Helsinki: Information Centre of the Ministry of Agriculture and Forestry.

[43] TIKE (2006). Maatalouden rakennetutkimus 2003, Maatilojen muu yritystoiminta. Helsinki: Information Centre of the Ministry of Agriculture and Forestry. 


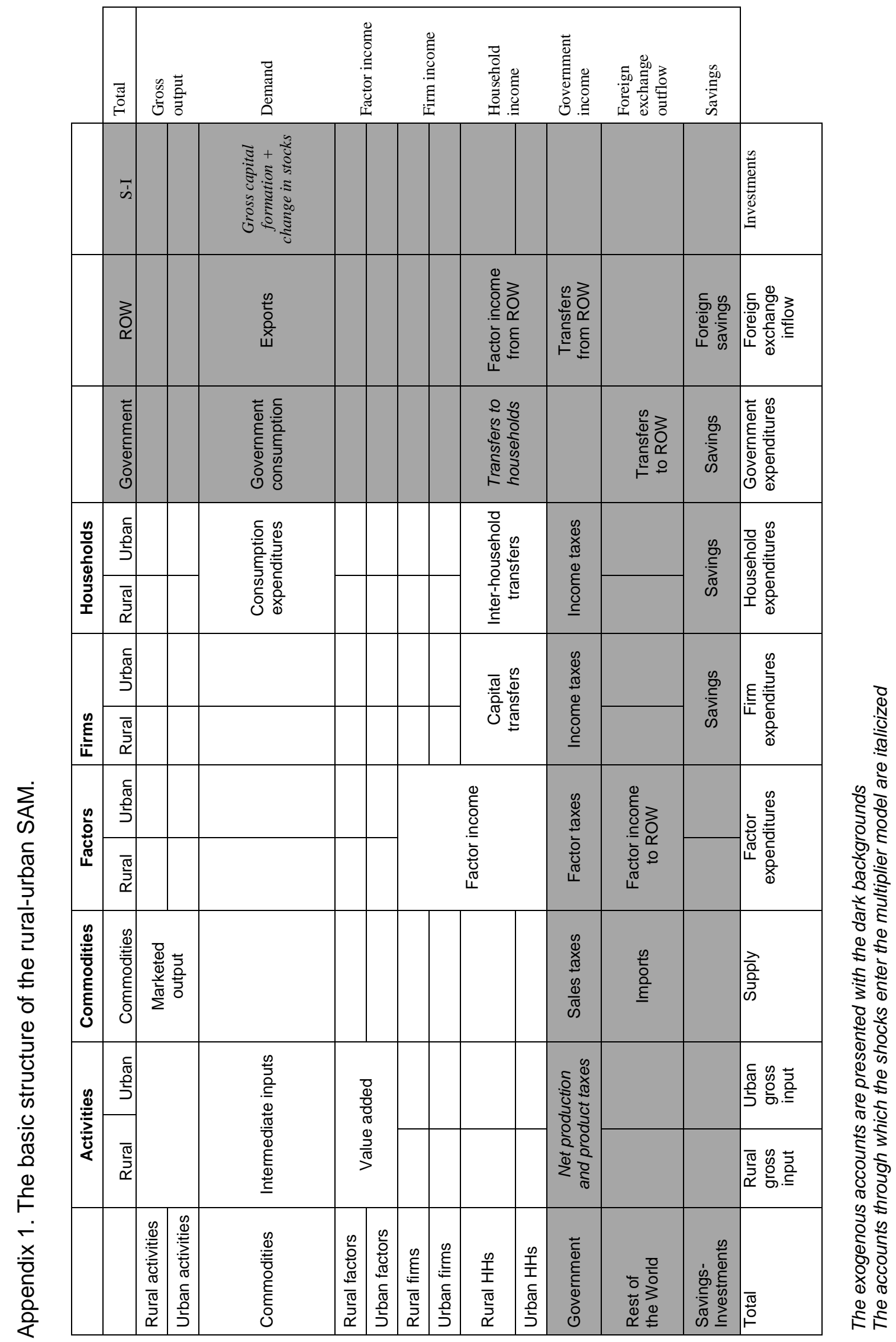


Appendix 2

Agriculture scenarios

\begin{tabular}{|c|c|c|c|c|c|c|c|c|}
\hline \multirow{2}{*}{\multicolumn{3}{|c|}{$\begin{array}{l}\text { Subsidy transfer to the diversified activity } \\
\text { South } \\
\text { Ostrobothnia }\end{array}$}} & \multirow{2}{*}{\multicolumn{2}{|c|}{ North Karelia }} & \multicolumn{4}{|c|}{ Increase in agricultural subsidy } \\
\hline & & & & & \multicolumn{2}{|c|}{ South Ostrobothnia } & \multicolumn{2}{|c|}{ North Karelia } \\
\hline & $\begin{array}{l}\text { Increase } \\
\text { in output } \\
(€ \text { mill })\end{array}$ & $\mathrm{Ch}(\%)$ & $\begin{array}{l}\text { Increase } \\
\text { in output } \\
(€ \text { mill })\end{array}$ & $\mathrm{Ch}(\%)$ & $\begin{array}{l}\text { Increase in } \\
\text { output } \\
\text { (€mill) }\end{array}$ & $\mathrm{Ch}(\%)$ & $\begin{array}{l}\text { Increase in } \\
\text { output } \\
\text { (€mill) }\end{array}$ & $\mathrm{Ch}(\%)$ \\
\hline A-Ragri & -68.968 & -17.99 & -25.169 & -17.444 & 25.739 & 6.713 & 9.039 & 6.265 \\
\hline A-Rdiv & 54.954 & 53.703 & 20.706 & 97.239 & 1.655 & 1.617 & 0.269 & 1.262 \\
\hline A-RPrim & -0.347 & -0.164 & -0.138 & -0.044 & 0.431 & 0.204 & 0.174 & 0.055 \\
\hline A-Rfood & -3.688 & -0.479 & -0.595 & -0.464 & 3.838 & 0.499 & 0.564 & 0.440 \\
\hline A-Rwood & -0.544 & -0.157 & -0.163 & -0.030 & 0.753 & 0.218 & 0.236 & 0.044 \\
\hline A-Rfuel & -0.945 & -1.302 & -0.771 & -0.325 & 0.564 & 0.777 & 0.444 & 0.187 \\
\hline A-Rtech & -0.912 & -0.121 & -0.250 & -0.087 & 1.289 & 0.171 & 0.268 & 0.093 \\
\hline A-Renergy & -0.080 & -0.171 & -0.055 & -0.110 & 0.319 & 0.679 & 0.112 & 0.223 \\
\hline A-Roth & -0.386 & -0.171 & -0.055 & -0.096 & 0.465 & 0.206 & 0.067 & 0.118 \\
\hline A-Rconstr & -0.238 & -0.064 & -0.058 & -0.025 & 0.381 & 0.102 & 0.119 & 0.051 \\
\hline A-Rtrade & -4.355 & -1.221 & -1.137 & -0.520 & 3.413 & 0.957 & 0.829 & 0.379 \\
\hline A-Rhotels & -0.130 & -0.235 & -0.029 & -0.068 & 0.253 & 0.458 & 0.066 & 0.154 \\
\hline A-Rtrans & -0.902 & -0.375 & -0.396 & -0.172 & 1.097 & 0.456 & 0.391 & 0.170 \\
\hline A-Rprivs & -2.435 & -0.328 & -0.276 & -0.078 & 4.000 & 0.538 & 0.731 & 0.206 \\
\hline A-Rpublics & -1.111 & -0.164 & -0.324 & -0.062 & 1.276 & 0.189 & 0.309 & 0.059 \\
\hline A-UPrim & -0.062 & -0.210 & & & 0.071 & 0.238 & & \\
\hline A-Ufood & -1.230 & -0.479 & -0.349 & -0.464 & 1.279 & 0.499 & 0.331 & 0.440 \\
\hline A-Uwood & -0.029 & -0.172 & -0.078 & -0.031 & 0.042 & 0.246 & 0.113 & 0.045 \\
\hline A-Ufuel & -0.207 & -1.312 & -0.415 & -0.325 & 0.123 & 0.781 & 0.239 & 0.187 \\
\hline A-Utech & -0.167 & -0.122 & -0.189 & -0.087 & 0.235 & 0.172 & 0.202 & 0.093 \\
\hline A-Uenergy & -0.038 & -0.171 & -0.083 & -0.110 & 0.150 & 0.679 & 0.169 & 0.223 \\
\hline A-Uoth & -0.018 & -0.176 & -0.029 & -0.096 & 0.021 & 0.210 & 0.036 & 0.118 \\
\hline A-Uconst & -0.097 & -0.064 & -0.031 & -0.025 & 0.156 & 0.102 & 0.064 & 0.051 \\
\hline A-Utrade & -2.145 & -1.221 & -0.823 & -0.520 & 1.681 & 0.957 & 0.600 & 0.379 \\
\hline A-Uhotels & -0.073 & -0.235 & -0.031 & -0.068 & 0.142 & 0.458 & 0.069 & 0.154 \\
\hline A-Utrans & -0.530 & -0.375 & -0.243 & -0.172 & 0.644 & 0.456 & 0.240 & 0.170 \\
\hline A-Uprivs & -1.088 & -0.327 & -0.415 & -0.078 & 1.787 & 0.538 & 1.106 & 0.207 \\
\hline A-Upublics & -0.543 & -0.165 & -0.314 & -0.062 & 0.626 & 0.190 & 0.295 & 0.058 \\
\hline Total & -36.316 & -0.518 & -11.711 & -0.206 & 52.428 & 0.748 & 17.085 & 0.301 \\
\hline Rural output & -30.088 & -0.562 & -8.710 & -0.258 & 45.470 & 0.849 & 13.620 & 0.403 \\
\hline Urban output & -6.228 & -0.377 & -3.001 & -0.131 & 6.958 & 0.422 & 3.465 & 0.151 \\
\hline
\end{tabular}




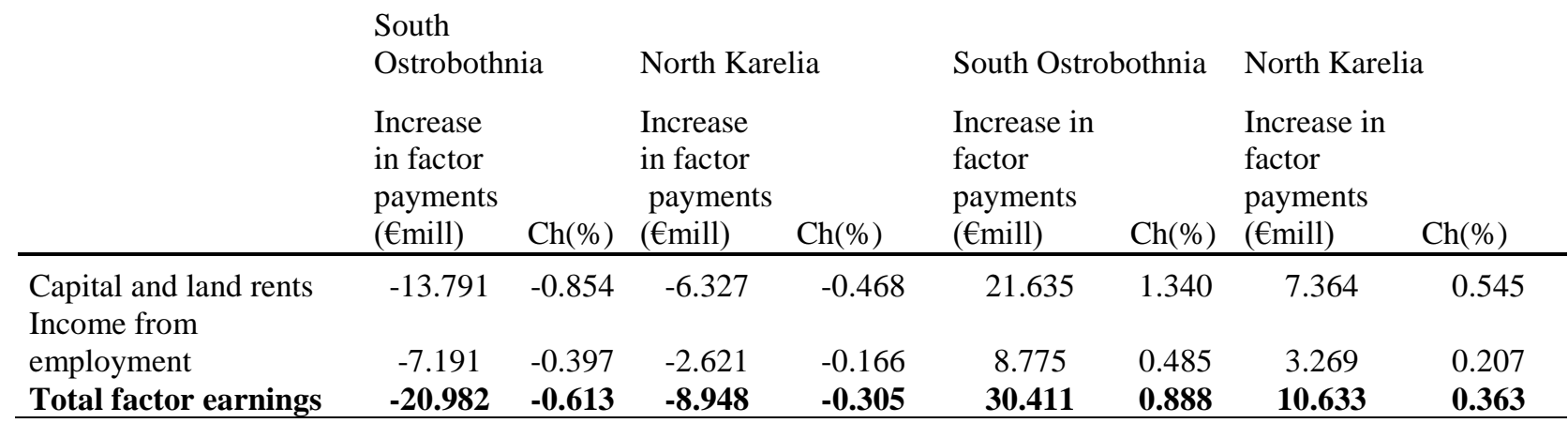

Household income changes

\begin{tabular}{|c|c|c|c|c|c|c|c|c|}
\hline & $\begin{array}{l}\text { South Ostrc } \\
\text { Increase } \\
\text { in } \\
\text { household } \\
\text { income } \\
\text { (€mill) }\end{array}$ & obothnia & $\begin{array}{l}\text { North Kare } \\
\text { Increase } \\
\text { in } \\
\text { household } \\
\text { income } \\
(€ m i l l)\end{array}$ & $\mathrm{Ch}(\%)$ & $\begin{array}{l}\text { Increase } \\
\text { in } \\
\text { household } \\
\text { income } \\
(€ \text { mill })\end{array}$ & obothnia & $\begin{array}{l}\text { Increase } \\
\text { in } \\
\text { household } \\
\text { income } \\
(€ \text { mill })\end{array}$ & $\mathrm{Ch}(\%)$ \\
\hline H-Agr & -7.867 & -1.804 & -5.539 & -3.539 & 13.246 & 3.038 & 4.027 & 2.573 \\
\hline H-Rwork & -3.871 & -0.338 & -1.343 & -0.158 & 5.024 & 0.438 & 2.016 & 0.237 \\
\hline H-Roth & -0.568 & -0.081 & -0.060 & -0.011 & 0.917 & 0.131 & 0.126 & 0.024 \\
\hline H-Rcom & -0.871 & -0.373 & -0.247 & -0.134 & 1.199 & 0.513 & 0.332 & 0.181 \\
\hline H-Uwork & -1.588 & -0.339 & -0.856 & -0.137 & 2.024 & 0.432 & 1.163 & 0.186 \\
\hline $\begin{array}{l}\text { H-Uoth } \\
\text { Rep- }\end{array}$ & -0.164 & -0.095 & -0.025 & -0.010 & 0.239 & 0.139 & 0.044 & 0.017 \\
\hline & 0.000 & 0.000 & 0.000 & 0.000 & 0.000 & 0.000 & 0.000 & 0.000 \\
\hline Total & -14.929 & -0.464 & -8.070 & -0.302 & 22.650 & 0.704 & 7.707 & 0.289 \\
\hline
\end{tabular}


Appendix 3. Infrastructure investment and tourism scenarios.

\begin{tabular}{|c|c|c|c|c|c|c|c|c|}
\hline \multicolumn{5}{|c|}{ Infrastructure investment } & \multicolumn{4}{|l|}{ Tourism } \\
\hline & \multicolumn{2}{|c|}{ South Ostrobothnia } & \multicolumn{2}{|c|}{ North Karelia } & \multicolumn{2}{|c|}{ South Ostrobothnia } & \multicolumn{2}{|c|}{ North Karelia } \\
\hline & $\begin{array}{l}\text { Increase } \\
\text { in } \\
\text { output } \\
(€ \text { mill }) \\
\end{array}$ & $\mathrm{Ch}(\%)$ & $\begin{array}{l}\text { Increase } \\
\text { in } \\
\text { output } \\
\text { (€mill) }\end{array}$ & $\mathrm{Ch}(\%)$ & $\begin{array}{l}\text { Increase } \\
\text { in } \\
\text { output } \\
\text { (€mill) }\end{array}$ & $\mathrm{Ch}(\%)$ & $\begin{array}{l}\text { Increase } \\
\text { in } \\
\text { output } \\
\text { (€mill) }\end{array}$ & $\mathrm{Ch}(\%)$ \\
\hline A-Ragri & 0.133 & 0.035 & 0.073 & 0.051 & 0.342 & 0.089 & 0.259 & 0.179 \\
\hline A-Rdiv & 0.038 & 0.038 & 0.011 & 0.054 & 0.103 & 0.100 & 0.038 & 0.177 \\
\hline A-RPrim & 0.077 & 0.037 & 0.100 & 0.032 & 0.111 & 0.053 & 0.137 & 0.044 \\
\hline A-Rfood & 0.255 & 0.033 & 0.086 & 0.067 & 0.528 & 0.069 & 0.253 & 0.197 \\
\hline A-Rwood & 0.150 & 0.043 & 0.167 & 0.031 & 0.195 & 0.056 & 0.186 & 0.035 \\
\hline A-Rfuel & 0.086 & 0.119 & 0.176 & 0.074 & 0.069 & 0.095 & 0.403 & 0.170 \\
\hline A-Rtech & 0.319 & 0.042 & 0.210 & 0.073 & 0.341 & 0.045 & 0.223 & 0.078 \\
\hline A-Renergy & 0.041 & 0.088 & 0.047 & 0.093 & 0.041 & 0.088 & 0.045 & 0.090 \\
\hline A-Roth & 0.087 & 0.039 & 0.041 & 0.071 & 0.163 & 0.072 & 0.076 & 0.133 \\
\hline A-Rconstr & 0.090 & 0.024 & 0.151 & 0.064 & 0.069 & 0.018 & 0.081 & 0.034 \\
\hline A-Rtrade & 0.373 & 0.105 & 0.295 & 0.135 & 0.775 & 0.217 & 0.356 & 0.163 \\
\hline A-Rhotels & 0.075 & 0.135 & 0.053 & 0.124 & 0.621 & 1.125 & 0.518 & 1.204 \\
\hline A-Rtrans & 4.461 & 1.854 & 4.133 & 1.799 & 0.840 & 0.349 & 0.886 & 0.386 \\
\hline A-Rprivs & 0.665 & 0.090 & 0.377 & 0.106 & 0.693 & 0.093 & 0.424 & 0.119 \\
\hline A-Rpublics & 0.169 & 0.025 & 0.122 & 0.023 & 0.191 & 0.028 & 0.130 & 0.025 \\
\hline A-UPrim & 0.013 & 0.045 & & & 0.018 & 0.061 & & \\
\hline A-Ufood & 0.085 & 0.033 & 0.050 & 0.067 & 0.176 & 0.069 & 0.148 & 0.197 \\
\hline A-Uwood & 0.010 & 0.057 & 0.080 & 0.032 & 0.010 & 0.060 & 0.089 & 0.035 \\
\hline A-Ufuel & 0.019 & 0.122 & 0.095 & 0.074 & 0.015 & 0.095 & 0.217 & 0.170 \\
\hline A-Utech & 0.058 & 0.043 & 0.157 & 0.072 & 0.062 & 0.045 & 0.169 & 0.077 \\
\hline A-Uenergy & 0.019 & 0.088 & 0.071 & 0.093 & 0.019 & 0.088 & 0.068 & 0.090 \\
\hline A-Uoth & 0.004 & 0.041 & 0.022 & 0.071 & 0.007 & 0.073 & 0.041 & 0.133 \\
\hline A-Uconst & 0.037 & 0.024 & 0.081 & 0.064 & 0.028 & 0.018 & 0.043 & 0.034 \\
\hline A-Utrade & 0.184 & 0.105 & 0.214 & 0.135 & 0.382 & 0.217 & 0.258 & 0.163 \\
\hline A-Uhotels & 0.042 & 0.135 & 0.055 & 0.124 & 0.349 & 1.125 & 0.539 & 1.204 \\
\hline A-Utrans & 2.620 & 1.854 & 2.533 & 1.799 & 0.493 & 0.349 & 0.543 & 0.386 \\
\hline A-Uprivs & 0.297 & 0.090 & 0.570 & 0.107 & 0.310 & 0.093 & 0.630 & 0.118 \\
\hline A-Upublics & 0.083 & 0.025 & 0.116 & 0.023 & 0.092 & 0.028 & 0.124 & 0.025 \\
\hline Total & 10.490 & 0.150 & 10.087 & 0.178 & 7.045 & 0.101 & 6.884 & 0.121 \\
\hline Rural output & 7.019 & 0.131 & 6.043 & 0.179 & 5.082 & 0.095 & 4.014 & 0.119 \\
\hline Urban output & 3.472 & 0.210 & 4.044 & 0.176 & 1.963 & 0.119 & 2.870 & 0.125 \\
\hline
\end{tabular}




\begin{tabular}{|c|c|c|c|c|c|c|c|c|}
\hline & \multicolumn{2}{|c|}{ South Ostrobothnia } & \multicolumn{2}{|c|}{ North Karelia } & \multicolumn{2}{|c|}{ South Ostrobothnia } & \multicolumn{2}{|c|}{ North Karelia } \\
\hline & $\begin{array}{l}\text { Increase } \\
\text { in factor } \\
\text { payments } \\
(€ m i l l)\end{array}$ & $\mathrm{Ch}(\%)$ & $\begin{array}{l}\text { Increase } \\
\text { in factor } \\
\text { payments } \\
(€ m i l l)\end{array}$ & $\mathrm{Ch}(\%)$ & $\begin{array}{l}\text { Increase } \\
\text { in factor } \\
\text { payments } \\
(€ m i l l)\end{array}$ & $\mathrm{Ch}(\%)$ & $\begin{array}{l}\text { Increase } \\
\text { in factor } \\
\text { payments } \\
(€ m i l l)\end{array}$ & $\mathrm{Ch}(\%)$ \\
\hline Capital and land rents & 3.772 & 0.234 & 3.587 & 0.266 & 1.879 & 0.116 & 1.835 & 0.136 \\
\hline employment & 2.726 & 0.151 & 2.521 & 0.159 & 1.789 & 0.099 & 1.721 & 0.109 \\
\hline Total factor earnings & 6.498 & 0.190 & 6.108 & 0.208 & 3.668 & 0.107 & 3.556 & 0.121 \\
\hline
\end{tabular}

Household income changes due to infrastructure and tourism scenarios

\begin{tabular}{|c|c|c|c|c|c|c|c|c|}
\hline & $\begin{array}{l}\text { South Ostro } \\
\text { Increase } \\
\text { in } \\
\text { household } \\
\text { income } \\
\text { (€mill) }\end{array}$ & obothnia & $\begin{array}{l}\text { North Karel } \\
\text { Increase } \\
\text { in } \\
\text { household } \\
\text { income } \\
(€ m i l l) \\
\end{array}$ & $\mathrm{Ch}(\%)$ & $\begin{array}{l}\text { South Ostro } \\
\text { Increase } \\
\text { in } \\
\text { household } \\
\text { income } \\
\text { (€mill) }\end{array}$ & obothnia & $\begin{array}{l}\text { North Karel } \\
\text { Increase } \\
\text { in } \\
\text { household } \\
\text { income } \\
\text { (€mill) }\end{array}$ & $\mathrm{Ch}(\%)$ \\
\hline H-Agr & 0.309 & 0.071 & 0.176 & 0.113 & 0.353 & 0.081 & 0.202 & 0.129 \\
\hline H-Rwork & 1.441 & 0.126 & 1.403 & 0.165 & 0.941 & 0.082 & 0.866 & 0.102 \\
\hline H-Roth & 0.186 & 0.027 & 0.074 & 0.014 & 0.134 & 0.019 & 0.038 & 0.007 \\
\hline H-Rcom & 0.350 & 0.150 & 0.273 & 0.148 & 0.207 & 0.088 & 0.182 & 0.099 \\
\hline H-Uwork & 0.720 & 0.154 & 0.986 & 0.158 & 0.414 & 0.088 & 0.643 & 0.103 \\
\hline $\begin{array}{l}\text { H-Uoth } \\
\text { Rep- } \\
\text { tourist }\end{array}$ & 0.086 & 0.050 & 0.049 & 0.019 & 0.047 & 0.027 & 0.029 & 0.011 \\
\hline Total & 3.091 & 0.096 & 2.960 & 0.111 & 8.183 & 0.255 & 7.930 & 0.298 \\
\hline
\end{tabular}

